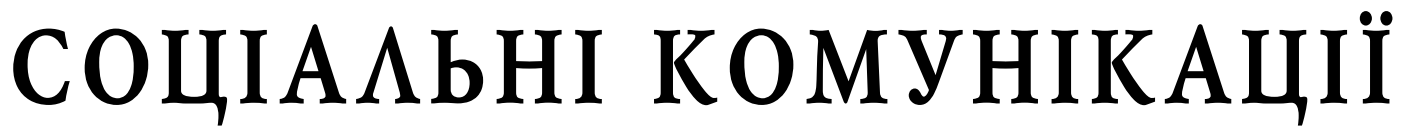

DOI: https://doi.org/10.32839/2304-5809/2021-4-92-49

УДК [316.77:004.77:7.04:616.98-036.21]"20"

Крохмальний P.O., Крохмальна С.P. Львівський національний університет імені Івана Франка

\section{ВІДЕОКОНТЕНТ СОЦМЕРЕЖ В УМОВАХ ПАНДЕМІЇ (ФУНКЦІОНАЛЬНИЙ, ДИДАКТИЧНИЙ І МИСТЕЦЬКИЙ КОНЦЕПТИ)}

\begin{abstract}
Анотація. Автори статті пропонують спробу аналізу окремих концептів відеоконтенту першого року пандемічних обмежень (березень 2020 - березень 2021 рр.). Ознаки фуннкціонального концепту сформовано умовами карантину, вони зазнавали змін залежно від маркерів фрнкціонування у соцмережі. Дидактичний концепт зумовлений одномоментно організованим велетенським простором дистанційного навчання на усіх рівнях. В його межах реалізовано чи не найбільше цікавих комунікативних навчальних акцій. Мистецький концепт зумовлений потребою віртуалізації творчих спроб учасників глобальної комунікації. Підставою для формування гіпотез і висновків цього дослідження стали окремі відеоматеріали, розміщені в рамках відповідного періоду в Youtube, Facebook, Instagram, Tik-Tok, Telegram. Динамічне середовище соціальних мереж не дає можливості формувати константи традиційного розуміння відеоматеріалу, оскільки сам об'єкт дослідження періодично зазнає метаморфоз різного гатунку, тому єдиним вірогідним методологічним засобом стала концептуалізація відеоконтенту і його комунікативного поля.
\end{abstract}

Ключові слова: відеоконтент, соціальні мережі, дистанційне навчання, пандемія, мистецький образ, автор, концепти комунікації, комунікативне поле.

Krokhmalnyi Roman, Krokhmalna Sofiia Ivan Franko National University of Lviv

\section{SOCIAL MEDIA VIDEO CONTENT DURING THE PANDEMIC (FUNCTIONAL, DIDACTIC, AND ARTISTIC CONCEPTS)}

Summary. The contributors offer herein an attempt of analysing certain video content concepts of the first year of pandemic restrictions (March 2020 - March 2021). The functional concept attributes shaped by the quarantine conditions underwent changes depending on the participants' acquisition of technological competences, awareness of the implementation of a common communication channel, quantitative characteristics of a feedback, frequency of video material release, and other markers of functioning in a social network. The didactic concept is driven by the instantly organized huge distance learning space at all levels. Within its framework the most interesting communicative learning activities have been realized. This concept and learning communication as such has undergone the most extensive transformations, marked not only by quantitative indicators, but also by changes in the methodological principle of interaction between participants. The pandemic year experience testifies both to the improvement of previously acquired methods of distance communication and to the emergence of completely new forms and methods, which may represent the first signs of learning communication of the near future. The artistic concept is determined by the need of virtualizing the creative endeavours of participants in global communication. The authorial self in the pandemic virtual space has not been deprived of the opportunity to receive a direct response from the consumers of aesthetic content, yet it has received limitations in terms of requirements of the social network communication algorithm. The artistic image of video content gains a kind of acceleration in relation to its creation, viewing and feedback. Members of artistic communities and the recipients of artistic content sometimes have mutually opposing goals - from replacing the real scene in the virtual space to creating a simulacrum of the virtual world. Several videos posted within the relevant period on Youtube, Facebook, Instagram, Tik-Tok, Telegram provided grounds for the development of hypotheses and derivation of conclusions in this study. The dynamic environment of social networks does not allow establishing any constants in the default understanding of video materials since the study object itself is periodically subjected to various metamorphoses. Hence, the conceptualization of video content and its communicative field was the only possible methodological tool.

Keywords: video content, social media, distance learning, pandemic, artistic image, author, communication concepts, communicative field.

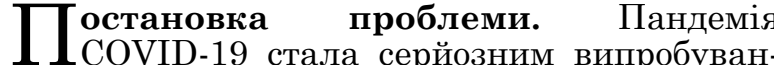
ням для усієї цивілізації. Усі галузі діяльності людини зазнали трагічного виклику, ще не подоланого на час написання статті. Роль відеоконтенту в соціальних мережах зростає пропорційно до швидкості поширення відео (вдосконалення технічних можливостей гаджетів та швидкість поширення Інтернету), разом із тим, засновники соцмереж-гігантів уже давно [йде мова про ви- ступ 2019 року засновника Facebook Марка Цукерберга URL: https://about.fb.com/news/2019/04/ f8-2019-day-1/] передбачають зростання ролі відеоматеріалу, створюють можливості для його динамічного поширення і спільного перегляду та обговорення. Пандемічні умови спричинили вибух уваги до онлайн-комунікації в соцмережах, а відеоконтент став ледь не єдиним рятівним засобом для представників багатьох профресій і видів діяльності. 
Аналіз останніх досліджень і публікацій. Питання адаптації людства до життя в умовах карантинних обмежень спричинило появу цілого ряду досліджень. Відзначимо своєрідну «першу ластівку у фраховому обговоренні зруйнованого навчання» [10, с. 5] - колективну монографію [10], де автори спробували здійснити первинний аналіз ситуації, що склалася упродовж 2020 року. Хоч відеоконтент як такий (А. Досенко, О. Жигаліна, О. Кузнецова, Л. Мальцева, Ю. Доброносова), його застосування з навчальною метою (Н. Ямшинська, Н. Сейко, Т. Батюта, Г. Поточняк) стали об'єктом досліджень ще у доепідемічний час, окремо виділимо дослідження психологічних особливостей навчальної комунікації епідемічного часу (В. Панок, І. Марухіна, Д. Романовська, В. Кремень, М. Слюсаревський, Л. Найдьонова, О. Вознесенська), лінгвістичний погляд на українські соцмережі (Л. Белей, С. Зайцева, В. Шпитальний, О. Синюта, А. Захарченко, А. Комнацька, С. Чемеркін, О. Коневщинська, В. Коптюрова); розгляд рис комунікації у зв'язку із розбудовою інформаційного суспільства (А. Гусєв, Н. Довгань, О. Івачевська, Н. Малеєва, І. Петренко); окреслення кризових комунікацій в умовах пандемії (О. Тодорчук, O. Скорук, S. Wedziuk); аналіз культурно-мистецької комунікації в карантинних обмеженнях (М. Чумаченко, Є. Буцикіна). Окрім того, численні дослідження у окресленому колі питань відображені в багатьох онлайн-конференщіях, семінарах, які «вибухнули» під впливом раптово оголошеного карантину.

Виділення невирішених раніше частин загальної проблеми. Перші спроби аналізу особливостей комунікації людської цивілізації в умовах пандемії COVID-19 позначили зміну кількісних характеристик («частота відвідування Facebook та YouTube зросла до 30\%, при цьому ці мережі стали «основним каналом розваг та соціалізації») [1]. Гіпотетично уже на початку дослідження можемо передбачити зміну якісних параметрів соціальних мереж щодо різних їх маркерів, при цьому візьмемо до уваги фонкціональні ознаки (оскільки змінилася мета застосування віртуального середовища, виникли потреби вдосконалення комунікації із використанням відеоконференщійного зв'язку), дидактичні ознаки (відеоконтент отримав статус головного комуніката в глобально переорієнтованому форматі), мистецькі ознаки (користувачі, які масово переходять у світ виключно віртуальної комунікації, зберігають властивість до художньо-образного, творчо активного світосприймання, а тому, мистецький світогляд, припускаємо, отримуе нові можливості).

Мета статті - дослідження окремих особливостей відеоконтенту соціальних мереж в умовах пандемії COVID-19 із використанням елементів концептуального аналізу явища віртуальної комунікації.

Виклад основного матеріалу. Відеоконтент як явище сощіальних мереж привернув до себе посилену увагу із збільшенням швидкості доступу до Інтернет. Кінець 2010-тих років засвідчив зростання явища відеоблогінгу (а відтак і зростання ознак поширення відеоконтенту), а тому і збільшення його присутності у різних соцмережах [8].
Функціональне розширення можливостей блогу як такого пов'язуемо із розвитком технічних можливостей користувачів, а також і з технологічними можливостями самих соцмереж.

Г. Поточняк ще у доепідемічний час відзначила і важливість «використання блогів в процесі навчання», i "використання мікроблогів», оскільки, на думку дослідниці, мікроблоги мають «високий ступінь взаемодії студентів», а це - «один із способів розвитку комунікативних навичок» [13, с. 185]. В умовах жорсткого карантину усе навчання стало дистанційним, а така комунікація - чи не единою.

В. Кухаренко та В. Бондаренко виділяють важливі типи взаемодії («студент-контент, студент-студент та студент-викладач») в рамках онлайн-навчання і приходять до висновку про те, що «наявність кожного з цих типів взаемодії, коли воно істотно інтегровано у навчальний процес, забезпечуе необхідні результати навчання» $[10$, с. 11]. Безальтернативна дистанційна освіта в умовах карантину, на відміну від її змішаної форми доепідемічного періоду, дала змогу для апробації різних форм віртуальної комунікації. Для поширення досвіду, обміну думками щодо проблем і ситуацій упродовж 2020 року проведено велику кількість вебінарів та веб-конференцій. Саме у цьому віртуальному середовищі сформувалися підходи до розуміння функціонального концепту онлайн відеконтенту в соціальних мережах.

Популярний серед української педагогічної спільноти проєкт «На урок» [вебсторінка (https://naurok.com.ua), FB-сторінка (https://www.facebook.com/naurok.com.ua), Telegram-канал (https://t.me/naurok), i Youtubeканал (https://www.youtube.com/c/НаУрок/ тощо]. Заснований ще у 2017 році, цей проект ставить собі досить амбітну мету («об’ективно висвітлювати сучасний освітній процес та вивести його на якісно новий рівень.» [URL: https://naurok.com. ua/page/about дата звернення 30.04.2021]. Кількісні характеристики усіх ресурсів цього проєкту 3 початком пандемії, цілком прогнозовано - із сучасної точки зору, мали зростання і частотності розміщення контенту (в т.ч. і відео), і зростання кількості переглядів. Найчастіше переглядали користувачі відеоматеріал Youtube - «Використання сервісу Zoom для проведення дистанційних занять» (опублікований 25 березня 2020 р., через менш ніж два тижні після початку локдауну). При аналізі елементів зворотнього зв'язку (чат, маркери пропорції лайків-дизлайків) можна переконатися у вчасності, доцільності зазначеного онлайн-відео, схвальні відгуки приводять до висновку не лише про попит на такий контент, але і вказують на цілком усвідомлену мотивацію користувачів щодо застосування об̆'єта відеокомунікації за його призначенням.

Як наслідок, дидактичний і функціональний концепти відеоконтенту отримали повноцінну підтримку і від Міністерства освіти і науки України (численні циркуляри, методичні семінари і тренінги онлайн), і від освітянських спільнот різного рівня. Один із висновків щодо повноцінного фонкціонування віртуального навчального середовища сформували В. Кухаренко та В. Бондаренко, визнавши ключовою вимогою навчаль- 
ної комунікації - відповідну до викликів високу кваліфрікацію викладача («Підготовка такого фрахівця вимагає напруженої праці 3 розробки дистанційного курсу протягом понад двох місящів») [10, с. 11-12]. Звичайно, твердження щодо терміну підготовки дистанщійного курсу має гіпотетичний кількісний вимір, проте для розуміння фрункціонального концепту відеоконтенту в навчальному процесі, переконливо можемо передбачити і більший термін, оскільки викладач так чи інакше буде змушений у процесі навчальної комунікації діяти гнучко, підлаштовуючи відеоконтент залежно від потреб віртуального середовища.

Особливості мистецького концепту спробувала актуалізувати Є. Буцикіна, відзначивши появу в умовах епідемічних обмежень «великої кількості нових майданчиків для перегляду та купівлі творів мистецтва, безліч лекцій, обговорень і воркшопів, низки експериментальних артпроектів. (...) об’єднує всі ці проекти перебування онлайн (частково або повністю)» [4]. Методологічно важливим є твердження Ю. Доброносової про те, що «найяскравіші відеоблоги з'являються на прикордонні масмедіа і мистецтва й уможливлені масовим поширенням цифрових технологій i розвитком соціальних мереж» [6, с. 90]. Таким чином, сучасне мистецтво і прискорене динамікою соціальної комунікації естетичне сприймання пересічного реципієнта, бурхливі швидкості життя на межі віртуального і реального світів, метаморфози художнього образу в межах такої своєрідної лімінальної зони - ось, на нашу думку, каталізатори сучасної мистецької свідомості в умовах віртуальної комунікації.

Як приклади, один із сучасних проєктів «Pangram - мистецький онлайн-простір, в якому презентуватимуть українське візуальне мистецтво, а також займатимуться питаннями авторського права»" [URL: https://supportyourart.com дата звернення 30.04.2021], або численні Youtube-канали українських театрів із відеотрансляціями old-записів чи сучасних онлайн постанов [9]. При перегляді таких онлайн-проєктів користувач соцмереж отримуе хоч і обмежені алгоритмами соціальної комунікації, проте в міру технологічних причин якісно інші віртуальні можливості осягнути естетику художнього образу, реалізувати свою оцінку явищ мистецької дійсності 3 допомогою інструментів зворотнього зв'язку.

Є. Буцикіна відзначила Instagram як «ключову платформу для комунікації, мережування та комерщійної діяльності галерей і художників за умов, коли фрізичні простори зачинені» і ви- ділила один із методів «взаємодії різних сторінок та користувачів» - «запуск хештегу» i, на думку дослідниці, «таких хештегів уже чимало: \#artinthetimeofcorona, \#artinquarantine, \#quarantineart, \#isolationart, \#covidart та \#covid19art тощо» [4]. Авторське «я» в умовах пандемічного віртуального простору хоч i не втратило можливості отримувати безпосередню реакцію споживачів естетичного контенту, проте набуло обмежень з т. зору вимог алгоритму комунікації соціальних мереж. Художній образ відеоконтенту отримує своєрідне прискорення щодо свого створення, перегляду і зворотнього зв'язку. Представники мистецьких спільнот і реципіенти мистецького контенту мають іноді взаємно протилежні цілі - від заміщення реальної сцени у віртуальному просторі до створення симулякра віртуального світу наяву.

Висновки i пропозиції. Відеоконтент соціальних мереж - сучасне динамічне комунікащійно-естетичне явище. В умовах карантину це явище отримало нові умови фрункціонування в різних галузях діяльності людини. Ознаки фрункціонального концепту сфрормовано умовами карантинних обмежень, зазнавали змін залежно від набуття учасниками відеокомунікації технологічних компетенцій, усвідомлення реалізації єдиного каналу комунікації, кількісних характеристик зворотного зв'язку, частотності публікації відеоматеріалу, інших маркерів функціонування у соцмережі. В його межах реалізовано чи не найбільше цікавих комунікативних навчальних акцій. Цей концепт і навчальна комунікація як така зазнали найбільш масштабних перетворень, позначених не лише кількісними показниками, але й зміною методологічного принципу взаємодії. Мистецький концепт відеоконтенту сформував свої вимоги і можливості для учасників віртуальної комунікації, відкрив безмежний горизонт для творення художнього образу, позначив межі для зворотнього зв'язку, але й проявив ностальгію за відчуттям реального світу.

Досвід пандемічного року засвідчуе зміну технологічних вимог до компетентностей фрахівців, збільшення швидкості сприймання контенту (iз зниженням якості усвідомлення естетики художнього образу), утвердження відеоконтенту як одної із найбільш поширених і переконливих динамічних форм комунікації у соціальних мережах. Окреслені ознаки дають підстави для гіпотези про зародження нових фором і методів глобальної комунікації, які можуть стати першими рисами віртуальної комунікації близького майбутнього, що потребує свого окремого уважного дослідження.

\section{Список літератури:}

1. 3 Tips for Nonprofit Organizations During the COVID-19 Pandemic. URL: https://www.marketingmaven.com/ 2020/06/16/3-tips-for-nonprofit-organizations-during-the-covid-19-pandemic/ (дата звернення: 30.04.2021).

2. Korrin Bishop. How COVID-19 Has Changed Social Media Trends (Як COVID-19 змінив тренди соціальних медіa). URL: https://www.classy.org/blog/how-covid-19-crends/?utm_source=paid_nptechforgood\&utm_ medium=email\&=paid_evergreen (дата звернення: 30.04.2021).

3. Wedziuk S. Komunikacja w czasie koronawirusa. URL: https://www.pb.pl/komunikacja-w-czasiekoronawirusa-989043 (дата звернення: 30.04.2021).

4. Буцикіна Є. Мистецький світ в умовах пандемії: нові формати. URL: http://www.korydor.in.ua/ua/stories/artworld-and-pandemia.html (дата звернення: 30.04.2021).

5. Гусев А. Комунікативні технології інформаційного суспільства : монографрія. Кропивницький : Імекс-ЛТд, 2020. 142 c.

6. Доброносова Ю. Медіакультурна специфріка відеоблогінгу як практики медіакомунікаціі. Вісник Львівського університету. Серія ббілособбські науки. 2019. Випуск 23. С. 85-91. 
7. Кремень В.Г. Психологія і педагогіка у протидії пандемії COVID-19 : інтернет-посібник. Київ : ТОВ «Юрка Любченка", 2020. URL: https://lib.iitta.gov.ua/719827/ (дата звернення: 30.04.2021).

8. Крохмальний Р.О., Крохмальний Д.Р. Відеоблог як явище сучасної інтернет-комунікації (дискурсивні маркери і когерентність образу). Молодий вчений. 2018. № 8(1). С. 18-21.

9. Крохмальний P.О., Крохмальна С.Р. Деякі концепти інтернет-комунікації в сучасному театральному мистецтві. Молодий вчений. 2020. № 4(1). С. 125-128.

10. Кухаренко В.М., Бондаренко В.В. Екстрене дистанційне навчання в Україні : монографія / За ред. В.М. Кухаренка, В.В. Бондаренка. Харків : Вид-во КП «Міська друкарня», 2020. 409 с.

11. Панок В.Г. Результати дослідження психологічного стану учасників освітнього процесу в умовах пандемії COVID-19. Вісник Національної акаделії педагогічних наук Украӥни. 2021. № 3(1). С. 1-6.

12. Панок В.Г., Марухіна І.В. Романовська Д.Д. Психологічний супровід освіти в умовах пандемії. Вісник Національної акаделії педагогічних наук Украӥни. 2020. № 2(2). С. 1-7.

13. Поточняк Г.І. Використання відеоблогів на практичних заняттях з англійської мови. Молодий вчений. 2019. № 4. C. $182-185$.

14. Тодорчук О. Комунікації під час пандемії : лекція. URL: https://bazilik.media/komunikatsii-pid-chas-pandemiilektsiia-oleksandra-todorchuka

15. Чумаченко М.О. Дистанційне навчання як відповідь на виклики сучасності: культурно-мистецький аспект. Культура і сучасність : альланах. № 1. Київ : ІДЕЯ ПРИНТ, 2020. С. 43-50.

\section{References:}

1. 3 Tips for Nonprofit Organizations During the COVID-19 Pandemic. URL: https://www.marketingmaven.com/ 2020/06/16/3-tips-for-nonprofit-organizations-during-the-covid-19-pandemic/

2. Korrin Bishop. How COVID-19 Has Changed Social Media Trends (Yak COVID-19 zminyv trendy socialnyx media). URL: https://www.classy.org/blog/how-covid-19-/?utm_source=paid_npt=paid_evergreen

3. Wedziuk S. Komunikacja w czasie koronawirusa. URL: https://www.pb.pl/komunikacja-w-czasiekoronawirusa-989043 (accessed 30 April 2021).

4. Bucykina Ye. Mysteczkyj svit v umovax pandemiyi: novi formaty [The art world in a pandemic: new formats]. URL: http://www.korydor.in.ua/ua/stories/art-world-and-pandemia.html

5. Gusyev A. (2020) Komunikatyvni texnologiyi informacijnogo suspilstva [Communication technologies of information society]. Kropyvnyczkyj: Imeks-LTD. (in Ukrainian)

6. Dobronosova Yu. (2019) Mediakulturna specyfika videoblogingu yak praktyky mediakomunikaciyi [Mediacultural specifics of video blogging as a practice of media communication]. Visnyk Lvivskogo universytetu. Seriya filosofski nauky, vol. 23, pp. 85-91.

7. Kremen V.G. (2020) Psyxologiya i pedagogika u protydiyi pandemiyi COVID-19 : internet-posibnyk [Psychology and pedagogy in counteracting the COVID-19 pandemic: an online guide]. Kyiv: TOV "Yurka Lyubchenka». URL: https://lib.iitta.gov.ua/719827/ (in Ukrainian)

8. Krokhmalny R.O., Krokhmalny D.R. (2018) Videoblog yak yavyshhe suchasnoyi internet-komunikaciyi (dyskursyvni markery i kogerentnist obrazu) [Video blog as a phenomenon of modern internet communication (discursive markers and image coherence)]. Molodyj vchenyj, vol. 8(1), pp. 18-21.

9. Krokhmalny R.O., Krokhmalna S.R. (2020) Deyaki koncepty internet-komunikaciyi v suchasnomu teatralnomu mystecztvi [Some internet communication concepts in contemporary theatrical art]. Molodyj vchenyj, vol. 4(1), pp. 125-128.

10. Kuxarenko V.M., Bondarenko V.V. (2020) Ekstrene dystancijne navchannya v Ukrayini: monografiya [Emergency distance learning in Ukraine: Monograph]. Xarkiv: Vyd-vo KP «Miska drukarnya». (in Ukrainian)

11. Panok V.G. (2021) Rezultaty doslidzhennya psyxologichnogo stanu uchasnykiv osvitnogo procesu v umovax pandemiyi COVID-19 [The results of a study of the psychological state of participants in the educational process in a pandemic COVID-19]. Visnyk Nacionalnoyi akademiyi pedagogichnyx nauk Ukrayiny, vol. 3(1).

12. Panok V.G., Maruxina I.V., Romanovska D.D. (2020) Psyxologichnyj suprovid osvity v umovax pandemiyi [Psychological support of education in a pandemic]. Visnyk Nacionalnoyi akademiyi pedagogichnyx nauk Ukrayiny, vol. 2(2).

13. Potochnyak G.I. (2019) Vykorystannya videoblogiv na praktychnyx zanyattyax z anglijskoyi movy [Using videoblogs in english classes]. Molodyj vchenyj, vol. 4, pp. 182-185.

14. Todorchuk O. Komunikaciyi pid chas pandemiyi: lekciya [Communications during a pandemic: a lecture]. URL: https://bazilik.media/komunikatsii-pid-chas-pandemii-lektsiia-oleksandra-todorchuka

15. Chumachenko M.O. (2020) Dystancijne navchannya yak vidpovid na vyklyky suchasnosti: kulturno-mysteczkyj aspekt [Distance learning as a response to modern challenges: cultural and artistic aspect]. Kultura $i$ suchasnist: almanax. Kyiv: IDEYa PRYNT, vol. 1, pp. 43-50. 